\title{
Hargitai, Peter. 2013. Who Let the Bats Out? Twisted Tales from Transylvania. Bloomington: iUniverse. 170 pp., illus. Dianne Marlene Hargitai
}

\section{Reviewed by Mártha Pereszlényi-Pintér, John Carroll University}

Peter Hargitai is an irascible, irreverent, yet irresistible iconoclast in this batty collection of sixteen rejuvenated and retold tales of revelry you will surely relish. So, prepare yourself to be robustly riveted and roused! These tales are meant to tease, teach, and chiefly to amuse. Warning: For those of a certain age and background, these are not the "nice" and romanticized tales you might have heard at your mother's knee! (And surely not your grandmother's knee either!). Should you be unfamiliar with the literary terrain of Transylvania, you will not find it here; neither will you find any banter or bathos in this brazen barrage of twisted tales. So do not be baffled by the bold, bawdy stories, which in another time and place might have been banned, bowdlerized and bleeped.

But first, a little about the author: Peter Hargitai was born in 1947 in Budapest, Hungary. At the age of nine, he wrote his first poem, "Rebels," meant as a tribute to the failed 1956 Hungarian Revolution. After a daring escape with his father, mother, and two brothers, he arrived in America. Hargitai was twenty when he married Dianne Marlene Kress, his illustrator for these tales. His literary career began with poems published while still in college at Cleveland State University. He later discovered and translated the poems of Hungarian poet Attila József (1905-1937), as well as taught at several schools in the Cleveland area. In 1978, Hargitai and his family left Cleveland for Florida, where he secured a position at the University of Miami teaching composition and English and American literature, and later at Florida International University in Miami, where he was to work as a professor until his retirement in 2012. Among his works, there are several collections of original poems, several literary translations, a volume of short stories, a collection of folktales, three novels, a massive two-volume textbook about the Hungarian exilic experience, and many other literary successes. In addition, over the course of several decades he has been the recipient of numerous academic and literary awards.

In response to Who Let the Bats Out? Twisted Tales from Transylvania, one reviewer compared Hargitai to a new Woody Allen (http://www.amazon.com/Who-Let-Bats-OutTransylvania/dp/1475971613). He is not. Rather, he has created a twenty-first century homage to Geoffrey Chaucer's Canterbury Tales (begun circa 1387) and to Giovanni Boccaccio's Decameron (composed circa 1348-53). Hargitai thus joins the legacy of Hungarian literary authors apparently influenced in particular by the Decameron as well as by other European literary traditions that include eroticism combined with extreme violence (e.g., some of the French fabliaux). One might begin with Renaissance era Hungarian authors such as György Enyedi (1555-97), actually third bishop of the Unitarian church, but best known to researchers of old Hungarian literature as the author who rewrote and adapted into a Hungarian version Boccaccio's first tale of the fourth day or "The Story of Ghismonda and Guiscardo" [Gismunda

$($ (c) $)$ EY

ULIS D-Sente 
Pereszlényi-Pintér, Mártha. "Hargitai, Peter. 2013. Who Let the Bats Out? Twisted Tales from Transylvania." Hungarian Cultural Studies. e-Journal of the American Hungarian Educators Association, Volume 7 (2014): http://ahea.pitt.edu DOI: 10.5195/ahea.2014.158

és Gisquardus, 1574]. Here, the father of Ghismonda slays his daughter's lover, Guiscardo, and sends her Guiscardo's heart in a golden cup, from which she drinks poison and dies.

Perhaps some might consider it a stretch, but this reviewer sees a literary link for Hargitai with those Hungarian authors who borrow from a European or at least a Western literary tradition, but as Hungarian authors, while they do infuse these traditions into their own tales, they also reweave their tales with a strong sense of Hungarian pride and patriotism. They thereby rise to the task of keeping the national spirit alive, as did Maurus Jókai (Jókai Mór, 1825-1904) in the dark days following the failed Hungarian Revolution of 1848. Jókai drew upon a literary heritage and then "Hungarianized" it in his striking collection of short tales in ten volumes entitled Maurus Jókai’s Decameron (Jókai Mór Dekameronja. Száz novella; Budapest: Heckenast Gusztáv, 1858).

Moving into the twentieth century, one might mention folklorist Olga Nagy (1921-2006; see Kata Zsófia Vincze's article on Nagy's work in AHEA - E-Journal vol.6 (2013) at: http://ahea.net/sitefiles/file/journals/201311/Vincze-final.pdf) and her Peasant-Decameron (Paraszt-dekameron; Budapest: Magvetö, 1977). Nagy dismantles folk and rural culture particularly in Hungarian Transylvania, as her stories or, in fact, adaptations like those of Hargitai, are not exactly the ancient, pure, and beautifully romanticized and idealized national gems and treasures of Hungarian folk culture. They are not beautiful legends, folksongs and ballads, because Nagy through her own fieldwork in real villages found that peasant folklore was not necessarily aesthetic, innocent, or morally immaculate. Perhaps her stories were an inspiration for the brazen to bawdy Paraszt-Dekameron, a very popular, and sexy animated Hungarian TV series (2001).

Hargitai's Hungarian-American homage to Boccaccio has its counterparts as postmodern parables in Hungary itself with the publication of Éva Bánki's enormously popular Hungarian Decameron (Magyar Dekameron; Budapest: Magvetö, 2007). In this modern variation on Boccaccio's masterpiece the characters, like those of Boccaccio, flee the plague but this time by traveling through space and time, and eventually they arrive in the residential suite of the Budapest Hotel in Hungary. The tales string together love affairs as well as ordinary to outrageous atrocities raging from the sensual to the senseless. In addition, in the early twentyfirst century, numerous literary storytelling competitions have sprung up in Hungary in search for fresh, original short stories or tales by aspiring new writers within the framework of the "Kis Magyar Dekameron" [Little Hungarian Decameron]. Competitions included those sponsored by the Unió Film Production Company, in cooperation with Hungarian television stations. Prizes have been awarded by "Litera," the Hungarian Web based literature portal, with winners invited to transform their tales into film scripts for a television series of the same title.

Hargitai's role as literary successor to those seminal authors will become all the more evident with an overview of a few of his tales in his slim but stimulating volume titled Who Let the Bats Out? Twisted Tales from Transylvania. In the first tale of the collection, "Chasing the Miraculous Hind," twin hunters Hunor and Magor soar in the heavens like two shooting stars, oddly obsessed by the behind of a magical white hind. In the end, all the characters alight in the Carpathian basin, where they meet a beguilingly beautiful moon maiden named Snow White. The maiden is attended by seven dwarves, each representing a different ethnic minority, with each minority claiming first settlement of the Carpathian basin.

In the tale "Who Let the Bats Out?" that lent its title to the whole collection, Hargitai pleasantly perverts the fairy tale convention whereby everything occurs in threes. In this tale, three princesses Sun, Moon, and Star meet three peasant shepherd lads: Illés, Péter (the village 
Pereszlényi-Pintér, Mártha. "Hargitai, Peter. 2013. Who Let the Bats Out? Twisted Tales from Transylvania." Hungarian Cultural Studies. e-Journal of the American Hungarian Educators Association, Volume 7 (2014): http://ahea.pitt.edu DOI: 10.5195/ahea.2014.158

simpleton), and Áron. As in many tales where the hero lends assistance to a creature in need and is later rewarded by magical means, Péter saves the life of a sickly animal, an anthropomorphic ass, who as a reward for his savior stomps his hoof thrice: three tendrils become three twigs which in turn become not three shepherd crooks but three lightning rods for the three brothers. "Count to three and something magical will happen," the ass promises. Three more stomps and three perfumed hankies float in the air. The rods and hankies most probably symbolize male and female essences, and possibly mating. In the meantime, the headstrong King has hidden his three daughters and let all the bats out of the caves. The bats in turn blot out the light of the sun, the moon and the stars. But inadvertently the stubborn King's curse and his crazed bats have also turned his trusted dragoons into dragons.

"The Fruits of Black Magic" is a tale vaguely reminiscent of "Beauty and the Beast." A princess ends up with a porcine partner who claims to be Bacchus, the King of Wine, but he is merely a filthy swine that lacks the noble character of the familiar Beast. In "The White Deer and his Party," the hero White Deer is depicted at first as a whiney mama's boy. After finally being forced to leave home, White Deer learns that among his first acts was an inadvertent beating of his father to a pulp. Though clearly suffering of oedipal tendencies, White Deer is not content to consult Freudian, Jungian, or Ericksonian therapies, but only Yoda from Star Wars. As in the dictum "Go West, Young Man," White Deer (in this execution of the motif of the hero's journey) bypasses the People's Republic of Hungary and eventually lands in East Berlin with a fake passport, only to meet a STASI (East German State Security) agent dressed as Little Red Riding Hood, who turns out to be the sexy Katerina Witt, former East German Olympic ice skating star.

"The King and His Royal Castle" is Hargitai's homage to his American hometown of Cleveland and its now long-gone fast food chain, Royal Castle. All Clevelanders of a certain age will recall that Royal Castle is not at all the same as the more familiar White Castle restaurant chain. King Mátyás lives in his "Royal Castle," an obvious reference to this old Cleveland iconic hamburger restaurant that specialized in burgers with fried onions, fries, and its famous five cent birch beer served in a frosted mug. Hargitai also pays homage to his illustrator wife, by inventing in his tale "The Real Dracula" a figure called "the beautiful Marlene Kress von Kressenstein," a girl of noble birth from Franconia. Hargitai's poetic roots are revealed in references to fellow poets in the same tale. For example, the father of the prince-to-be Dracula admonishes him with "Do Not Go Gentle into That Goodnight [sic]," which is an obvious reference to the twentiethcentury Welsh poet Dylan Thomas. Hargitai's future Prince Dracula later playfully and openly plagiarizes Dylan Thomas when telling the Emperor of Bats that he is seeking a kingdom "Where Death Shall Have No Dominion." In addition, part of the hero's journey is to visit the graves of Béla Lugosi and Boris Karloff, two 1930s horror movie actors with foreign sounding accents. Hargitai's ability to play with words and his clever command of language are also evident in his reference to a character named Rózsa (Rose), who in the tale of "The Rose and the Thorn" becomes a "thorn" in her lesbian lover Ibolya's side. Another example of Hargitai's clever word play occurs in the tale entitled "The Real Dracula," in which the bats that fly in Vformation become the "V-empire of Bats."

Anachronisms or rather insertions of present-day popular culture and food-ways abound in all the tales: iPods, iPads, tin cans and string are Verizon's calling devices. Not only Bram Stoker but also Sherlock Holmes and Dr. Watson turn up in Transylvania, after which the latter two end up in a gay marriage. We read about Havana cigars and elves from Guatemala, dosages of Dristan that seduce a princess, along with references to Robitussin, Ritalin, Ambien, and Botox. Hargitai's tales are also sprinkled with references such as the Atkins Diet, Marlboro 
Pereszlényi-Pintér, Mártha. "Hargitai, Peter. 2013. Who Let the Bats Out? Twisted Tales from Transylvania." Hungarian Cultural Studies. e-Journal of the American Hungarian Educators Association, Volume 7 (2014): http://ahea.pitt.edu DOI: 10.5195/ahea.2014.158

cigarettes, a turbo-charged silver carriage, Brokeback Mountain, Budweiser the "King" of Beers, Dolly Parton, Victoria's Secret, Mad Dog 20/20, Beefeater gin, and Paul Anka records. King Mátyás the Just pops up in not just one but in several of the tales, as does Elizabeth Báthory, the Blood Countess whose occasional early seventeenth century defenses of mistreated women are compared to those of detective Mariska Hargitai of the television program "Law and Order: Special Victims Unit," who happens to be the daughter of Hungarian bodybuilder Mickey Hargitai (but with no relation to author Hargitai) and Jayne Mansfield.

In these stories you also meet straight serpent-like creatures and gay super-heroes, tattooed dragon slayers, medieval shepherds whose lies tell the truth, talking cocks stalking Turkish emperors, and a blind princess under the spell of an evil witch. You will even meet a lovely damsel who not only dreams but also fulfills her impossible dream of becoming a king, after an extended vacation and an apparent sex-change operation in neighboring Serbia. So, should this collection of twisted tales be labeled scurrilous, scatological, and scandalous? Not really, for as Hargitai himself observes in the "Author's Notes," he has merely let the bats out of his imagination by going beyond the usual liberties taken with any oral tradition or modern popular culture. The same is true for Hargitai's adding, subtracting, altering or redressing tales and myths to suit his intentions as he targets the needs of today's imagined audience; for these twisted tales surely mirror the tastes of today's reading and zip-zapping public. Hargitai freely admits taking "perverse delight" in combining ancient Hungarian myths with American pop culture in unusual and irreverent ways. He admits poking fun at both, with parody, irony, and at times his own selfadmitted "insanity."

Does Hargitai sacrilegiously take aim at sacrosanct Hungarian myths and legends? Perhaps he does. But on the other hand, his work is the literary descendant of not only the folktale and the Decameron traditions, but also of what literary historians revere as the fabliaux -- those medieval French tales that were most frequently ribald narratives and which were immensely popular with the nobility of the court as well as with the peasantry and city folk. Both Hargitai's tales and these medieval genres frequently revolve around trickery, practical jokes, sexual mishaps, scatology, mistaken identity, and bodily humor. For sure, Hargitai's parody and satire are oftentimes dominated by allusions to primary needs (eating, drinking, defecating, mating) to celebrate the victory of life. The social and the corporeal are joyfully joined in an indivisible, universal and beneficial world. Finally, especially for those of Hungarian origin among Hargitai's readers, all this is sprinkled with large doses of paprika, very hot paprika! 